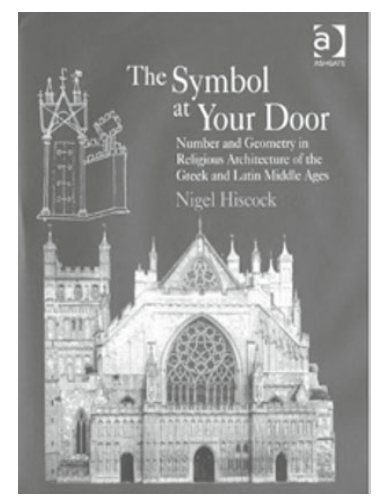

Keywords: church, baptistery, basilica, centrally-planned building, chapter house, Middle

Ages, meaning, symbolism, geometry, harmonic proportion, measurement, number, Platonic solids, sacred geometry, shapes

\title{
The Symbol at Your Door: Number and Geometry in Religious Architecture of the Greek and Latin Middle Ages
}

Aldershot: Ashgate, 2007

Reviewed by Areli Marina

School of Architecture

University of Illinois

117 Temple Buell Hall, MC 621

611 Lorado Taft Drive

Champaign, IL 61820 USA

amarina@illinois.edu

In his previous book, The Wise Master Builder: Platonic Geometry in Plans of Medieval Abbeys and Cathedrals (Aldershot: Ashgate, 2000), Nigel Hiscock sought to demonstrate that Platonic geometry underlay the ground plans of Western European Romanesque cathedrals and abbey churches, but refrained from arguing that these geometric and numerological foundations had symbolic meanings. In The Symbol at Your Door, he sets out to prove that medieval church design is pervaded with numbers and geometric forms that express metaphysical concepts central to Christian neoPlatonism. In Hiscock's view, this symbolism was deliberately inscribed into the structures by the buildings' designers at the behest of their patrons. He argues that religious buildings that can be parsed into measures that correspond to Pythagorean number theory and broken down into fragments that coincide with Platonic geometry exist in such large numbers that the correspondences cannot be coincidental, but rather must have been intended by either patrons or builders. Furthermore, because there is so much evidence that well-educated medieval persons associated particular numbers, ratios, and geometric forms with Christian significance (such as the association of the number three with the Trinity, the square with the shape of the Holy Jerusalem, or the sphere with heaven), Hiscock concludes that patrons and designers must have meant to elicit those meanings in the mind of their viewers.

As the author acknowledges, this controversial hypothesis contradicts an influential strain of medieval architectural historiography that asserts that medieval builders used geometry and number purely for functional and not for representational purposes. This school of thought is exemplified by the work of Lon R. Shelby, John Harvey, François Bucher, or (more recently) Robert Bork, and emerges from the French nineteenthcentury rationalist tradition of Eugene Emmanuel Viollet-le-Duc. Hiscock positions himself in a different genealogy, identifying his conceptual roots in the iconographic investigations of Richard Krautheimer, Erwin Panofsky, and Paul Frankl, among others. In fact, The Symbol at Your Door can be read as a prolonged meditation on questions suggested by Frankl in "The Secrets of the Mediaeval Masons" in 1945 (Art Bulletin 27, 
n. 1, pp. 46-60): What means did medieval builders use to develop their buildings' plans, elevations, and decoration? How were these ideas communicated in the workshop? Why were the equilateral triangle and the square so important to medieval design practice? How were the metaphysical concepts about shape and measure presented by Plato in the Timaeus transmitted in the Middle Ages? What do these practices reveal about the relationship between the underlying geometry, workshop practice, aesthetic pleasure, and religious ideology? Although these are not new questions, most have never been conclusively resolved, and Hiscock's in-depth exploration of them is a welcome addition to the discourse.

The author divides his investigation into four parts. In the substantial Prologue, he examines the historiography of medieval architectural history and introduces the reader to Pythagorean and Platonic thought, its transmission in the Middle Ages, and its impact on architectural culture. This section digests material treated more fully in The Wise Master Builder. It outlines the relationship between arithmetic and the numbers perceived to be at the root of universal order (particularly 1,2, 3, and 4) and the meanings attributed to them by ancient philosophers and Christian theologians. Chapters 1 and 2 constitute the second part of the book, in which the author explores the significance of two solid geometric forms, the sphere and the cube, as well as their deployment in cruciform churches. Chapters 3 through 6 are dedicated to the architectural use and meaning of plane figures: the equilateral triangle and the numbers derived from it $(3,6,12)$; the square, square schematism, quadrature, and its associated forms, including the $1: \sqrt{2}$ rectangle; the pentagon; and, in the last and longest chapter, circles, octagons, and other polygons. The book closes with an Epilogue in which the author summarizes his findings and considers their post-medieval implications.

To counter the arguments of the "rationalist school" and prove his hypothesis, Hiscock surveys and presents two bodies of classical and medieval textual sources and juxtaposes them with his analyses of medieval buildings. The first body of textual sources, including citations from authors such as Augustine, Boethius, and Dionysus, the PseudoAeropagite, demonstrates that number and geometric form conveyed specific metaphysical meaning to educated audiences. The second shows that when writing ekphrases and other eulogistic texts on buildings, or using buildings as metaphors, medieval authors such as Eusebius and William Durandus often adopted the same numerological and geometric topoi. The range of sources cited by Hiscock is impressive; the bibliography includes 157 citations of ancient and medieval works. Relatively few of these writers, however, present direct evidence about a specific building at or around the time of its construction, and Hiscock focuses on those examples only briefly (pp. 37-38). $\mathrm{He}$ is most persuasive when discussing the abundance of evidence relating to a single building structure, such as Hagia Sophia in Istanbul (Chapter 1), or when he introduces new questions, such as why the expressive content of the stone tracery of stained glass windows is seldom considered when discussing their iconographic programs (Chapter 6).

The book's impressive breadth of scope is also its principal weakness. Hiscock conjures so many examples, cites so many authors, and illustrates so many buildings to prove his point that the vigor of his argument is dissipated in seemingly endless, often redundant, and occasionally contradictory exposition. Even the author seems to get lost in this thicket of evidence, suggesting, for example, that the burial and commemorative function of English cathedral chapter houses did not account for the choice of a polygonal plan on page 255, only to assert on page 257 that because chapter houses functioned as memorial shrines, they often imitated the octagonal form of baptisteries, 
mausolea, and martyria. Also, his persistent use of the passive voice obscures the agency with which he wants to endow patrons, designers, and builders, and often obfuscates his meaning. Judicious editorial pruning would have focused the narrative, and resulted in a more legible and ultimately more convincing text.

In the end, Hiscock cannot quite dispel the lingering doubt that, although highlyeducated clerics and patrons may have been well-versed in the metaphysical aspects of number and geometric form, there is little consistent proof that either designers, builders, or audiences were equally familiar with them, much less across several centuries and from the British Isles to Asia Minor. Indeed, in cases where texts directly addressing geometry and number in relation to active workshops survive, such as the well-known debate regarding the design of Milan cathedral, they are silent on the subject of meaning and symbolic content (see especially pp. 366-370).

The philosopher Karl Popper has suggested that scientific theories cannot be proven true; at best, scientists can only refute untrue hypotheses. The volume of evidence amassed by Hiscock powerfully suggests, but does not prove, a strong causal relationship between the existence of Pythagorean and Platonic numbers and figures in medieval religious buildings and the symbolic interpretations of the buildings and building components made by their contemporaries. As in Frankl's day, the weak link remains the connection between the mind of the patron and the builder's hand (Frankl, 50). Insights into this aspect of the problem may lie, not within the purview of architectural history, but in the hands of our colleagues exploring the histories of medieval education and science.

In sum, The Symbol at Your Door is an ambitious book that is not afraid to engage a complex and controversial question. Hiscock's introduction to the metaphysics of number in the medieval period and the veritable anthology of medieval writings on architecture that he has assembled will be useful launching pads for future studies of how (or perhaps whether) the numbers and geometric forms embedded in specific medieval religious buildings had symbolic meaning. The wide range of his analyses reminds us of the richness and diversity of signification that architectural forms convey to their past and present audiences.

\section{About the reviewer}

Areli Marina, who trained as an art historian at the Institute of Fine Arts, New York University, teaches medieval and Renaissance architectural history at the University of Illinois. Her research focuses on the intersection of public rhetoric, national identity, and civic art production, particularly in relation to the semiotics of architecture and urban form; the problematic historiography of the Romanesque, Gothic, and Renaissance styles; and the role of antiquity in medieval and Renaissance art and architecture, with particular emphasis on northern Italy. Her work has been supported by a Rome Prize Fellowship at the American Academy in Rome, a Getty Foundation Fellowship, the Gladys Krieble Delmas Foundation, and the University of Illinois. Dr. Marina has recently completed a book on the medieval piazza, The Italian Piazza Transformed: Parma's City Center in the Communal Age, which will be published by Pennsylvania State University Press. During 2010-11, she hopes to make significant progress on a new book on medieval and Renaissance baptisteries while a Villa I Tatti fellow at the Harvard Center for Italian Renaissance Studies in Florence. 